\title{
Gambaran pasien gagal jantung akut yang menjalani rawat inap di RSUP Prof Dr. R. D. Kandou periode September-November 2016
}

\author{
${ }^{1}$ Devina E. Haris \\ ${ }^{2}$ Starry H. Rampengan \\ ${ }^{2}$ Edmond L. Jim
}

\author{
${ }^{1}$ Kandidat Skripsi Fakultas Kedokteran Universitas Sam Ratulangi Manado \\ ${ }^{2}$ Bagian Kardiologi Fakultas Kedokteran Universitas Sam Ratulangi Manado \\ Email: devinaestherina22@gmail.com
}

\begin{abstract}
Acute Heart Failure is marked by a fast/rapid attack or sudden changes in symptoms or signs of Heart Failure. Heart failure has become a main issue in cardiology, because of an increasing number of Heart Failure patients and frequent re-hospitalization and death and disability. The most common cause of heart failure is coronary artery disease and hypertension. Patients with heart failure have typical symptoms, such as shortness of breath at rest or activity, easily tired, leg edema, and also tachycardia, tachypnea, pulmonary ronkhi, pleural effusion, increased jugular venous pressure, peripheral edema, hepatomegaly, and structural abnormalities or functional heart symptoms at rest, such as cardiomegaly, third heart sound, and increased levels of natriuretic peptides.
\end{abstract}

Keywords: acute heart failure, inpatients care

\begin{abstract}
Abstrak: Gagal jantung akut adalah serangan yang cepat/rapid onset atau terjadinya perubahan mendadak dari gejala atau tanda gagal jantung. Gagal jantung telah menjadi masalah yang utama pada bidang kardiologi, karena bertambahnya jumlah penderita gagal jantung dan seringnya terjadi rawat ulang serta kematian dan kecacatan. Penyebab tersering gagal jantung di adalah penyakit arteri koroner dan hipertensi. Pasien yang mengalami gagal jantung memiliki gejala yang khas yaitu sesak napas saat istirahat atau aktifitas, mudah lelah, edema tungkai, dan terdapat juga tanda-tanda khas yaitu takikardi, takipnea, ronkhi paru, efusi pleura, peningkatan tekanan vena jugularis, edema perifer, hepatomegali, dan terdapat kelainan struktural atau fungsional jantung saat pasien istirahat yaitu kardiomegali, suara jantung ketiga, meningkatnya kadar peptida natriuretik.
\end{abstract}

Kata kunci: gagal jantung akut, rawat inap

Gagal jantung adalah suatu keadaan dimana jantung tidak lagi mampu memompa pasokan darah, untuk mempertahankan sirkulasi adekuat sesuai kebutuhan tubuh meskipun tekanan pengisian cukup. ${ }^{1,2}$

Menurut American Heart Association di Amerika terdapat 5,3 juta orang yang mengalami gagal jantung dan setiap tahun terdiagnosis 600.000 kasus baru, dengan insiden 10 per 1.000 orang. $^{3}$

Menurut data Riskesdas 2013, di Indonesia diperkirakan 229.696 orang atau sekitar
$0,13 \%$ mengalami gagal jantung berdasarkan diagnosis dokter, sedangkan berdasarkan diagnosis dokter atau gejala sebanyak 530.068 orang atau $0,3 \%{ }^{4}$

Menurut dara Riskesdas 2013, di Sulawesi Utara diperkirakan 2.378 orang mengalami gagal jantung berdasarkan diagnosis dokter, sedangkan berdasarkan diagnosis dokter atau gejala sebanyak 6.795 orang. ${ }^{4}$

Gagal jantung telah menjadi masalah yang utama pada bidang kardiologi, karena 
bertambahnya jumlah penderita gagal jantung dan seringnya terjadi rawat ulang serta kematian dan kecacatan. ${ }^{5}$

Penyebab tersering gagal jantung dib. negara maju adalah penyakit arteri koroner dan hipertensi, sedangkan penyebab tersering di negara berkembang adalah penyakit katup jantung dan malnutrisi, tetapi terdapat banyak hal juga yang dapat menjadi penyebab penyakit gagal jantung. ${ }^{6}$

Pasien yang mengalami gagal jantung memiliki gejala yang khas yaitu sesak napas saat istirahat atau aktifitas, mudah lelah, edema tungkai, dan terdapat juga tanda-tanda khas yaitu takikardi, takipnea, ronkhi paru, efusi pleura, peningkatan tekanan vena jugularis, edema perifer, hepatomegali, dan terdapat kelainan struktural atau fungsional jantung saat pasien istirahat yaitu kardiomegali, suara jantung ketiga, meningkatnya kadar peptida natriuretik. $^{7}$

Menurut penelitian dari Harikatang et $a l$, penyakit gagal jantung lebih sering dialami oleh laki-laki dibandingkan perempuan, berdasarkan usia didapatkan pada usia 60-70 tahun dibandingkan kelompok usia $\leq 60$ tahun, sedangkan berdasarkan penyebab penyakit terdahulu, menunjukkan terbanyak adalah penyakit $\mathrm{PJK}^{8}$

Berdasarkan data tersebut, maka peneliti tertarik untuk mengetahui gambaran pasien gagal jantung akut yang menjalani rawat inap di RSUP Prof. Dr. R. D. Kandou.

Gagal jantung akut adalah serangan yang cepat/rapid onset atau terjadinya perubahan mendadak dari gejala atau tanda gagal jantung. Menurut Guidelines European Society of Cardiology (ESC) 2008, gagal jantung akut mengkategorikan pasien menurut :

a. New onset atau de novo HF (kurang lebih 20\% dari total semua pasien gagal jantung akut). Pada pasien de novo HF terlihat untuk pertama kalinya gejala gagal jantung akut. Sering kali, tidak ditemukan adanya riwayat kardiovaskuler atau faktor risiko untuk gagal jantung, namun kadang pasien memiliki riwayat atau faktor resiko atau kelainan struktur jantung sebelumnya. ${ }^{13}$

Gagal jantung perburukan. Pada pasien ini, pasien memiliki riwayat gagal jantung kronik dan menunjukkan episode dekompensasi. ${ }^{9}$

\section{METODE PENELITIAN}

Penelitian yang dilakukan bersifat deskriptif prospektif dengan metode potong lintang untuk mengetahui gambaran pasien gagal jantung akut yang menjalani rawat inap di RSUP Prof. Dr. R. D. Kandou dengan menggunakan data sekunder dari rekam medik pasien sebagai acuan. Data penelitian akan dilakukan selama 10 minggu pada bulan September - November 2016. Pasien yang diambil menjadi sampel adalah yang memenuhi kriteria inklusi, yaitu pasien didiagnosis menderita gagal jantung akut yang menjalani rawat inap di RSUP Prof. Dr. R. D Kandou Manado pada periode September-November 2016, pasien yang memiliki data-data lengkap. Pasien yang masuk kriteria eksklusi adalah pasien yang tidak didiagnosis menderita gagal jantung akut yang menjalani rawat inap di RSUP Prof. Dr. R. D Kandou Manado pada periode September-November 2016, pasien yang tidak memiliki data-data lengkap dan belum pulang sampai batas penelitian. Variabel penelitian ini adalah usia, jenis kelamin, fraksi ejeksi, faktor pencetus, etiologi dan obat-obatan. Metode pengumpulan data yang digunakan dalam penelitian ini adalah menggunakan kuisioner pada pasien gagal jantung akut

\section{HASIL PENELITIAN}

Dari penelitian yang telah dilakukan di bagian Kardiologi RSUP Prof. Dr. R. D Kandou Manado sejak bulan September 2016 hingga November 2016, didapatkan 78 pasien gagal jantung akut yang memenuhi kriteria inklusi dan 5 pasien gagal jantung akut yang tidak memiliki data rekam medik yang lengkap sehingga dieksklusi.

Berdasarkan jenis kelamin, dari 78 pasien gagal jantung akut didapatkan 44 
$(56,4 \%)$ pasien laki-laki dan $34(43,6 \%)$ pasien perempuan (Tabel 1).

Tabel 1. Distribusi Sampel Berdasarkan Kelompok Jenis Kelamin

\begin{tabular}{lcc}
\hline Jenis Kelamin & $\begin{array}{c}\text { Jumlah } \\
(\mathbf{n = 7 8})\end{array}$ & $\mathbf{( \% )}$ \\
\hline Laki-Laki & 44 & $56,4 \%$ \\
Perempuan & 34 & $43,6 \%$ \\
\hline
\end{tabular}

Berdasarkan usia, dari 78 pasien gagal jantung akut didapatkan $7(9,0 \%)$ pasien dengan kelompok usia <40 tahun, 10 $(12,8 \%)$ pasien dengan kelompok usia 4049 tahun, $13(16,7 \%)$ pasien dengan kelompok usia 50-59 tahun, dan 48 $(61,5 \%)$ dengan kelompok usia $>60$ tahun (Tabel 2).

Tabel 2. Distribusi Sampel Berdasarkan Kelompok Usia

\begin{tabular}{lcc}
\hline $\begin{array}{c}\text { Usia } \\
\text { (Tahun) }\end{array}$ & $\begin{array}{c}\text { Jumlah } \\
(\mathbf{n = 7 8})\end{array}$ & $(\boldsymbol{\%})$ \\
\hline$<40$ & 7 & $9,0 \%$ \\
$40-49$ & 10 & $12,8 \%$ \\
$50-59$ & 13 & $16,7 \%$ \\
$>60$ & 48 & $61,5 \%$ \\
\hline
\end{tabular}

Berdasarkan fraksi ejeksi, dari 78 pasien gagal jantung akut didapatkan 24 $(30,8 \%)$ pasien dengan fraksi ejeksi $<40 \%$, $22(28,2 \%)$ pasien dengan fraksi ejeksi $40-$ $49 \%)$, dan $32(41,0 \%)$ pasien dengan fraksi ejeksi $>50 \%$ (Tabel 3).

Tabel 3. Distribusi Sampel Berdasarkan Kelompok Fraksi Ejeksi

\begin{tabular}{lcc}
\hline $\begin{array}{c}\text { Fraksi } \\
\text { Ejeksi }(\boldsymbol{\%})\end{array}$ & $\begin{array}{c}\text { Jumlah } \\
(\mathbf{n = 7 8 )}\end{array}$ & $\mathbf{( \% )}$ \\
\hline$<40 \%$ & 24 & $30,8 \%$ \\
$40-49 \%$ & 22 & $28,2 \%$ \\
$>50 \%$ & 32 & $41,0 \%$ \\
\hline
\end{tabular}

Berdasarkan etiologi, dari 78 pasien gagal jantung akut didapatkan $57(73,1 \%)$ pasien dengan etiologi penyakit jantung koroner, $22(28,2 \%)$ pasien dengan etiologi kelainan katup, $46(59,0 \%)$ pasien dengan etiologi hipertensi, $3(3,8 \%)$ pasien dengan etiologi penyakit jantung bawaan, dan $2(2,6 \%)$ pasien dengan etiologi kardiomiopati dan miokarditis (Tabel 4).

Tabel 4. Distribusi Sampel Berdasarkan Etiologi

\begin{tabular}{lcc}
\hline \multicolumn{1}{c}{ Etiologi } & $\begin{array}{c}\text { Jumlah } \\
(\mathrm{n}=78)\end{array}$ & $(\%)$ \\
\hline Penyakit Jantung & 57 & $73,1 \%$ \\
Koroner & 22 & $28,2 \%$ \\
Kelainan Katup & 46 & $59,0 \%$ \\
$\begin{array}{l}\text { Hipertensi } \\
\text { Penyakit Jantung }\end{array}$ & 3 & $3,8 \%$ \\
$\begin{array}{l}\text { Bawaan } \\
\text { Kardiomiopati } \\
\text { dan Miokarditis }\end{array}$ & 2 & $2,6 \%$ \\
\hline
\end{tabular}

Berdasarkan faktor pencetus, dari 78 pasien gagal jantung akut didapatkan 21 $(26,9 \%)$ pasien dengan faktor pencetus sindrom koroner akut, $25(32,1 \%)$ pasien dengan faktor pencetus aritmia cordis, 9 $(11,5 \%)$ pasien dengan faktor pencetus tidak patuh diet, $32(41,0 \%)$ pasien denganfaktor pencetus hipertensi tidak terkontrol, $11(14,1 \%)$ pasien dengan faktor pencetus tidak patuh mengkonsumsi obat, $12(15,4 \%)$ pasien dengan faktor pencetus pneumonia, dan $26(33,3 \%)$ pasien dengan pasien dengan faktor pencetus perburukan fungsi ginjal (Tabel 5).

Tabel 5. Distribusi Sampel Berdasarkan Faktor Pencetus

\begin{tabular}{|c|c|c|}
\hline Faktor Pencetus & $\begin{array}{l}\text { Jumlah } \\
(\mathrm{n}=78)\end{array}$ & $(\%)$ \\
\hline $\begin{array}{l}\text { Sindrom Koroner } \\
\text { Akut }\end{array}$ & 21 & $26,9 \%$ \\
\hline Aritmia Cordis & 25 & $32,1 \%$ \\
\hline Tidak Patuh Diet & 9 & $11,5 \%$ \\
\hline $\begin{array}{l}\text { Hipertensi Tidak } \\
\text { Terkontrol }\end{array}$ & 32 & $41,0 \%$ \\
\hline $\begin{array}{l}\text { Tidak Patuh } \\
\text { Mengkonsumsi } \\
\text { Obat }\end{array}$ & 11 & $14,1 \%$ \\
\hline Pneumonia & 12 & $15,4 \%$ \\
\hline $\begin{array}{l}\text { Perburukan Fungsi } \\
\text { Ginjal }\end{array}$ & 26 & $33,3 \%$ \\
\hline
\end{tabular}

Berdasarkan obat-obatan selama di rumah sakit, dari 78 pasien gagal jantung 
Haris, Rampengan, Jim: Gambaran pasien gagal...

akut didapatkan $78(100,0 \%)$ pasien yang menggunakan penyekat EKA/ARB, 56 $(71,8 \%)$ pasien yang menggunakan beta blocker, $43(55,1 \%)$ pasien yang menggunakan antagonis aldosteron, 28 $(35,9 \%)$ pasien yang menggunakan nitrat, $63(80,8 \%)$ pasien yang menggunakan diuretik (Tabel 6).

Tabel 6. Distribusi Sampel berdasarkan Obat-Obatan Selama di Rumah Sakit

\begin{tabular}{lcc}
\hline Pengobatan di RS & $\begin{array}{c}\text { Jumlah } \\
(\mathrm{n}=78)\end{array}$ & $(\%)$ \\
\hline Penyekat & 78 & $100,0 \%$ \\
EKA/ARB & 56 & $71,8 \%$ \\
Beta Blocker & 43 & $55,1 \%$ \\
Antagonis & 28 & $35,9 \%$ \\
Aldosteron & 63 & $80,8 \%$ \\
Nitrat & Diuretik & \\
\hline
\end{tabular}

Keterangan : $A R B=$ Angiotensin Reseptor Blocker, EKA = Enzim Konversi Angiotensin

Berdasarkan obat-obatan pulang, dari 78 pasien gagal jantung akut didapatkan 78 $(100,0 \%)$ pasien yang menggunakan penyekat EKA/ARB, $56(71,8 \%)$ pasien yang menggunakan beta blocker, 46 $(59,0 \%)$ pasien yang menggunakan antagonis aldosteron, $23(29,5 \%)$ pasien yang menggunakan nitrat, $59 \quad(75,6 \%)$ pasien yang menggunakan diuretik (Tabel 7).

Tabel 7. Distribusi Sampel berdasarkan Obat-Obatan Selama di Rumah Sakit

\begin{tabular}{lcc}
\hline \multicolumn{1}{c}{$\begin{array}{c}\text { Pengobatan } \\
\text { Pulang }\end{array}$} & $\begin{array}{c}\text { Jumlah } \\
(\mathbf{n = 7 8})\end{array}$ & $\mathbf{( \% )}$ \\
\hline Penyekat & 78 & $100,0 \%$ \\
EKA/ARB & 56 & $71,8 \%$ \\
Beta Blocker & 46 & $59,0 \%$ \\
Antagonis & 23 & $29,5 \%$ \\
Aldosteron & 59 & $75,6 \%$ \\
Nitrat & ngiotensin Reseptor \\
Diuretik & ARB $=$ & ngiotersin \\
Keterangan : &
\end{tabular}

Jumlah penderita gagal jantung akut de novo berjenis kelamin laki-laki ada 10 orang, sedangkan untuk penderita dekompensasi GJK berjenis kelamin lakilaki ada 34 orang. Sementara penderita gagal jantung akut de novo berjenis kelamin perempuan ada 9 orang, sedangkan untuk penderita dekompensasi GJK berjenis kelamin perempuan ada 25 orang.

Berdasarkan distribusi usia penderita, kelompok usia $<40$ tahun untuk gagal jantung akut de novo 0 orang dan untuk dekompensasi GJK 7 orang, kelompok usia 40-49 tahun untuk gagal jantung akut de novo 1 orang dan untuk dekompensasi GJK 9 orang, kelompok usia 50-59 tahun untuk gagal jantung akut de novo 4 orang dan untuk dekompensasi GJK 9 orang, kelompok usia >60 tahun untuk gagal jantung akut de novo 14 orang dan untuk dekompensasi GJK 34 orang.

Kelompok dengan etiologi penyakit jantung koroner untuk gagal jantung akut de novo 18 orang dan untuk dekompensasi GJK 39 orang, kelompok dengan etiologi hipertensi untuk gagal jantung akut de novo 11 orang dan untuk dekompensasi GJK 35 orang, kelompok dengan etiologi kelainan katup untuk gagal jantung akut de novo 1 orang dan untuk dekompensasi GJK 21 orang, kelompok dengan etiologi kardiomiopati dan miokarditis untuk gagal jantung akut de novo 1 orang dan untuk dekompensasi GJK 1 orang, kelompok dengan etiologi penyakit jantung bawaan untuk gagal jantung akut de novo 0 orang dan untuk dekompensasi GJK 3 orang.

Kelompok dengan faktor pencetus sindrom koroner akut untuk gagal jantung akut de novo 6 orang dan untuk dekompensasi GJK 15 orang, kelompok dengan faktor pencetus aritmia cordis untuk gagal jantung akut de novo 5 orang dan untuk dekompensasi GJK 20 orang, kelompok dengan faktor pencetus tidak patuh pada diet untuk gagal jantung akut de novo 0 orang dan untuk dekompensasi GJK 9 orang, kelompok dengan faktor pencetus tidak patuh mengkonsumsi obat untuk gagal jantung akut de novo 0 orang dan untuk dekompensasi GJK 11 orang, kelompok dengan faktor pencetus pneumonia untuk gagal jantung akut de 
novo 5 orang dan untuk dekompensasi GJK 7 orang, kelompok dengan faktor pencetus hipertensi tidak terkontrol untuk gagal jantung akut de novo 7 orang dan untuk dekompensasi GJK 25 orang, dan kelompok dengan faktor pencetus kegagalan fungsi ginjal untuk gagal jantung akut de novo 4 orang dan untuk dekompensasi GJK 22 orang.

Berdasarkan fraksi ejeksi yang memiliki fraksi ejeksi $<40$ untuk gagal jantung akut de novo sebanyak 5 orang dan dekompensasi GJK sebanyak 19 orang, fraksi ejeksi 40-49 untuk gagal jantung akut de novo sebanyak 7 orang dan dekompensasi GJK sebanyak 15 orang, fraksi ejeksi >50 untuk gagal jantung akut de novo sebanyak 7 orang dan dekompensasi GJK sebanyak 25 orang. Hal ini mungkin disebabkan oleh oksigen tidak dapat tersalurkan di jaringan sehingga tekanan ventrikel kiri meningkat. ${ }^{28}$

Berdasarkan pengobatan di Rumah Sakit, pengobatan dengan menggunakan penyekat EKA/ARB pada gagal jantung akut de novo sebanyak 19 orang dan dekompensasi GJK sebanyak 59 orang, pengobatan dengan menggunakan Beta Blocker pada gagal jantung akut de novo sebanyak 10 orang dan dekompensasi GJK sebanyak 46 orang, pengobatan dengan menggunakan antagonis aldosteron pada gagal jantung akut de novo sebanyak 12 orang dan dekompensasi GJK sebanyak 31 orang, pengobatan dengan menggunakan nitrat pada gagal jantung akut de novo sebanyak 8 orang dan dekompensasi GJK sebanyak 20 orang, pengobatan dengan menggunakan penyekat EKA/ARB pada gagal jantung akut de novo sebanyak 19 orang dan dekompensasi GJK sebanyak 59 orang.

Berdasarkan pemberian pengobatan dengan menggunakan penyekat EKA/ARB pada gagal jantung akut de novo sebanyak 19 orang dan dekompensasi GJK sebanyak 59 orang, pengobatan dengan menggunakan Beta Blocker pada gagal jantung akut de novo sebanyak 10 orang dan dekompensasi GJK sebanyak 46 orang, pengobatan dengan menggunakan antagonis aldosteron pada gagal jantung akut de novo sebanyak 11 orang dan dekompensasi GJK sebanyak 32 orang, pengobatan dengan menggunakan nitrat pada gagal jantung akut de novo sebanyak 4 orang dan dekompensasi GJK sebanyak 19 orang, pengobatan dengan menggunakan penyekat EKA/ARB pada gagal jantung akut de novo sebanyak 19 orang dan dekompensasi GJK sebanyak 59 orang (Tabel 8).

\section{BAHASAN}

Penelitian mengenai gambaran pasien gagal jantung akut yang menjalani rawat inap di RSUP. Prof. Dr. R. D. Kandou periode September-November 2016. Didapatkan pasien gagal jantung akut yang memenuhi kriteria inklusi dan menjadi sampel penelitian sebanyak 78 orang dari 83 orang total pasien selama periode tersebut.

Berdasarkan penelitian didapatkan bahwa penderita gagal jantung akut terbanyak pada jenis kelamin laki-laki sebanyak 44 orang $(56,4 \%)$ daripada jenis kelamin perempuan sebanyak 34 orang $(43,6 \%)$. Hasil penelitian ini sama dengan hasil yang dilaporkan oleh Susan MJ dkk tahun 2009 yang mendapatkan bahwa insiden gagal jantung akut lebih rendah pada perempuan dibandingkan pada lakilaki. ${ }^{10}$ Menurut penelitian yang dilakukan MEDLINE dan CINAHL, penyakit gagal jantung lebih sering dialami oleh laki - laki dibandingkan perempuan. karena pada umumnya laki -laki lebih sering melakukan aktifitas fisik dibandingkan perempuan dan juga dipengaruhi oleh faktor gaya hidup, seperti kebiasaan merokok dan konsumsi alkohol. ${ }^{11}$

Berdasarkan usia pada penelitian ini didapatkan kelompok usia terbanyak pada kelompok usia >60 tahun sebanyak 48 orang $(61,5 \%)$, kemudian diikuti kelompok usia 50-59 tahun sebanyak 13 orang $(16,7 \%)$, kelompok usia 40-49 tahun sebanyak 10 orang $(12,8 \%)$, dan kelompok usia $<40$ tahun sebanyak 7 orang $(9,0 \%)$ 
Haris, Rampengan, Jim: Gambaran pasien gagal...

Tabel 8. Karakteristik Dasar Pasien Gagal Jantung Akut

\begin{tabular}{|c|c|c|c|}
\hline \multirow{3}{*}{ KARAKTERISTIK } & \multicolumn{3}{|c|}{ GAGAL JANTUNG AKUT } \\
\hline & DE NOVO & $\begin{array}{c}\text { DEKOMPENSAS } \\
\text { I GJK }\end{array}$ & TOTAL \\
\hline & $n=19$ & $n=59$ & $n=78$ \\
\hline \multicolumn{4}{|l|}{ JENIS KELAMIN } \\
\hline Laki-laki & $10(52,6 \%)$ & $34(57,6 \%)$ & $44(56,4 \%)$ \\
\hline Perempuan & $9(47,4 \%)$ & $25(42,4 \%)$ & $34(43,6 \%)$ \\
\hline \multicolumn{4}{|l|}{ USIA (TAHUN) } \\
\hline$<40$ & $0(0 \%)$ & $7(11,9 \%)$ & $7(9,0 \%)$ \\
\hline $40-49$ & $1(5,3 \%)$ & $9(15,3 \%)$ & $10(12,8 \%)$ \\
\hline $50-59$ & $4(21,1 \%)$ & $9(15,3 \%)$ & $13(16,7 \%)$ \\
\hline$>60$ & $14(73,7 \%)$ & $34(57,6 \%)$ & $48(61,5 \%)$ \\
\hline \multicolumn{4}{|l|}{ ETIOLOGI } \\
\hline Penyakit Jantung Koroner & $18(94,7 \%)$ & $39(66,1 \%)$ & $57(73,1 \%)$ \\
\hline Hipertensi & $11(57,9 \%)$ & $35(59,3 \%)$ & $46(59,0 \%)$ \\
\hline Kelainan Katup & $1(5,3 \%)$ & $21(35,6 \%)$ & $22(28,2 \%)$ \\
\hline Kardiomiopati dan Miokarditis & $1(5,3 \%)$ & $1(1,7 \%)$ & $2(2,6 \%)$ \\
\hline Penyakit Jantung Bawaan & $0(0 \%)$ & $3(5,1 \%)$ & $3(3,8 \%)$ \\
\hline \multicolumn{4}{|l|}{ FAKTOR PENCETUS } \\
\hline Sindrom Koroner Akut & $6(31,6 \%)$ & $15(25,4 \%)$ & $21(26,9 \%)$ \\
\hline Aritmia Cordis & $5(26,3 \%)$ & $20(33,9 \%)$ & $25(32,1 \%)$ \\
\hline Tidak patuh pada diet & $0(0 \%)$ & $9(15,3 \%)$ & $9(11,5 \%)$ \\
\hline Tidak Patuh Mengkonsumsi Obat & $0(0 \%)$ & $11(18,6 \%)$ & $11(14,1 \%)$ \\
\hline Pneumonia & $5(26,3 \%)$ & $7(11,9 \%)$ & $12(15,4 \%)$ \\
\hline Perburukan fungsi ginjal & $4(26,3 \%)$ & $22(37,3 \%)$ & $26(33,3 \%)$ \\
\hline Hipertensi tidak terkontrol & $7(36,8 \%)$ & $25(42,4 \%)$ & $32(78,2 \%)$ \\
\hline \multicolumn{4}{|l|}{ FRAKSI EJEKSI (\%) } \\
\hline$<40 \%$ & $5(26,3 \%)$ & $19(32,3 \%)$ & $24(30,8 \%)$ \\
\hline $40-49 \%$ & $7(36,8 \%)$ & $15(25,4 \%)$ & $22(28,2 \%)$ \\
\hline$>50 \%$ & $7(36,8 \%)$ & $25(42,4 \%)$ & $32(41,0 \%)$ \\
\hline \multicolumn{4}{|l|}{ PENGOBATAN SELAMA DI RS } \\
\hline Penyekat EKA/ARB & $19(100,0 \%)$ & $59(100,0 \%)$ & $78(100,0 \%)$ \\
\hline Beta Blocker & $10(52,6 \%)$ & $46(78,0 \%)$ & $56(71,8 \%)$ \\
\hline Antagonis Aldosteron & $12(63,2 \%)$ & $31(52,5 \%)$ & $43(55,1 \%)$ \\
\hline Nitrat & $8(42,1 \%)$ & $20(33,9 \%)$ & $28(35,9 \%)$ \\
\hline Diuretik & $13(68,4 \%)$ & $50(84,7 \%)$ & $63(80,8 \%)$ \\
\hline \multicolumn{4}{|l|}{ PENGOBATAN PULANG } \\
\hline Penyekat EKA/ARB & $19(100,0 \%)$ & $59(100,0 \%)$ & $78(100,0 \%)$ \\
\hline Beta Blocker & $10(52,6 \%)$ & $46(78,0 \%)$ & $56(71,8 \%)$ \\
\hline Antagonis Aldosteron & $11(57,9 \%)$ & $32(54,2 \%)$ & $43(55,1 \%)$ \\
\hline Nitrat & $4(21,1 \%)$ & $19(32,2 \%)$ & $23(29,5 \%)$ \\
\hline Diuretik & $11(57,9 \%)$ & $48(81,4 \%)$ & $59(75,6 \%$ \\
\hline
\end{tabular}

Keterangan $: A R B=$ Angiotensin Reseptor Blocker, GJK $:$ Gagal Jantung Kronik, EKA $=$ Enzim Konversi Angiotensin

. Hasil penelitian ini sama dengan hasil yang dilaporkan oleh Susan MJ dkk yang mendapatkan bahwa pasien yang masuk dengan gagal jantung akut terbanyak pada kelompok usia $>65$ tahun. $^{10}$ Hal ini disebabkan karena pada pasien usia lanjut, pembuluh darah sudah tidak lagi elastis dan fleksibel, sehingga mengakibatkan plak atau lemak lebih mudah menumpuk dan menghalangi aliran darah sehingga terjadi aterosklerosis yang merupakan salah satu penyebab penyakit jantung koroner, yang bisa berkelanjutkan menjadi gagal jantung. ${ }^{12}$ 
Berdasarkan hasil penelitian penyebab gagal jantung akut terbanyak adalah penyakit jantung koroner yaitu sebanyak 57 orang $(73,1 \%)$, pasien dengan penyebab hipertensi yaitu sebanyak 46 orang $(59,0 \%)$, pasien dengan penyebab kelainan katup yaitu sebanyak 22 orang $(28,2 \%)$, pasien dengan penyebab penyakit jantung bawaan yaitu sebanyak 3 orang $(3,8 \%)$, dan pasien dengan kardiomiopati dan miokarditis sebanyak 2 orang $(2,6 \%)$. Hasil ini seperti yang di publikasikan pada artikel diseases and conditions heart failure tahun 2016 yang mendapatkan bahwa penyakit jantung koroner merupakan penyebab paling umum pada gagal jantung akut. ${ }^{13}$ Tingginya angka PJK pada penelitian ini dapat terjadi karena penelitian ini di lakukan di tanah Minahasa, hal ini sesuai dengan penelitian Grace kandou tahun 2005 yang menyatakan pengkomsumsi makanan khas Mihahasa dengan frekuensi makan $>2$ kali/ bulan berisiko mengalami PJK 4 kali lebih besar daripada pengkonsumsi <1 kali/ bulan. ${ }^{14}$

Berdasarkan hasil penelitian faktor pencetus gagal jantung akut adalah pasien dengan sindrom koroner akut yaitu sebanyak 21 orang $(26,9 \%)$, pasien dengan aritmia yaitu sebanyak 25 orang $(32,1 \%)$, pasien dengan tidak patuh diet yaitu sebanyak 9 orang $(11,5 \%)$, pasien dengan hipertensi tidak terkontrol yaitu sebanyak 32 orang $(41,0 \%)$, pasien dengan tidak patuh mengkonsumsi obat yaitu sebanyak 11 orang $(14,1 \%)$, pasien dengan pneumonia yaitu sebanyak 12 orang $(15,4 \%)$, dan pasien dengan perburukan fungsi ginjal yaitu sebanyak 26 orang $(33,3 \%)$. Hasil ini sama dengan hasil dari penelitian University of Maryland Medical Center tahun 2015 bahwa hipertensi tidak terkontrol merupakan faktor pencetus utama gagal jantung. Pada kenyataannya, sekitar $75 \%$ kasus gagal jantung mulai dengan hipertensi. ${ }^{15}$ Hal ini sesuai dengan penelitian Suzanne Oprail dkk. bahwa penyebab utama hipertensi tidak terkontrol adalah ketidakpatuhan pasien pada pengobatan dan terapi yang tidak tepat. ${ }^{16}$

Dari hasil penelitian menunjukkan bahwa jumlah pasien terbanyak adalah dengan fraksi ejeksi <40 yaitu sebanyak 24 orang (30,8\%), fraksi ejeksi 40-49 sebanyak 22 orang $(28,2 \%)$, dan diikuti fraksi ejeksi $>50$ sebanyak 32 orang $(41,0 \%)$. Hasil ini sama dengan hasil dari penelitian Krista SW dkk bahwa penderita gagal jantung akut terbanyak dengan fraksi ejeksi $>50 .{ }^{17}$ Hal ini mungkin disebabkan oleh oksigen tidak dapat tersalurkan di jaringan sehingga tekanan ventrikel kiri meningkat. ${ }^{18}$

Dari hasil penelitian didapatkan jumlah sampel yang diberi pengobatan selama di Rumah Sakit, pengobatan dengan penyekat EKA/ARB yaitu sebanyak 78 orang (100,0\%), Beta Blocker yaitu sebanyak 56 orang $(71,8 \%)$, Antagois Aldoteron yaitu sebanyak 43 orang $(55,1 \%)$, nitrat yaitu sebanyak 28 orang $(35,9 \%)$, dan diuretik yaitu sebanyak 63 orang $(80,8 \%)$. Hasil ini sama dengan hasil dari penelitian National Medicine Information Center bahwa pengobatan selama di Rumah Sakit terbanyak dengan menggunakan penyekat EKA/ARB. Dimana penyekat EKA/ARB dapat menghambat sistem renin angiotensin aldosteron (RAAS), dengan cara memblokir angiotensin 1 menjadi angiotensin 2 , dan yang mana telah terbukti untuk mengurangi angka kematian. Reseptor angiotensin blocker (ARB) juga memblokir RAAS, dengan menghambat pengikatan angiotensin II untuk angiotensin II, ARB dianjurkan untuk digunakan pada pasien gagal jantung sebagai alternatif untuk ACEIs (intoleransi ACEI). ${ }^{19}$

Dari hasil penelitian didapatkan jumlah sampel yang diberi pengobatan pulang penyekat EKA/ARB yaitu sebanyak 78 orang (100,0\%), Beta Blocker yaitu sebanyak 56 orang $(71,8 \%)$, Antagois Aldoteron yaitu sebanyak 46 orang $(59,0 \%)$, nitrat yaitu sebanyak 23 orang $(29,5 \%)$, dan Diuretik yaitu sebanyak 59 orang $(75,6 \%)$. Hasil dari penelitian Markku SN tahun 2006 bahwa pengobatan pulang terbanyak dengan diuretik $(90,1 \%){ }^{20}$ 
Haris, Rampengan, Jim: Gambaran pasien gagal...

\section{SIMPULAN}

Berdasarkan hasil penelitian mengenai gambaran pasien gagal jantung yang menjalani rawat inap di RSUP. Prof. Dr. R. D. Kandou Manado periode September November 2016 telah dilaksanakan, dan dari hasil penelitian dapat disimpulkan total pasien gagal jantung akut yang menjalani rawat inap di RSUP. Prof. Dr. R. D. Kandou Manado periode SeptemberNovember 2016 sebanyak 83 orang dan 78 orang yang memenuhi kriteria inklusi.

Gambaran pasien gagal jantung akut yang menjalani rawat inap di RSUP. Prof. Dr. R. D. Kandou Manado periode September-November 2016 ditemukan jenis kelamin laki-laki 44 orang $(56,4 \%)$. Kelompok usia terbanyak $>60$ tahun $(61,5 \%)$.

Gambaran pasien gagal jantung akut yang menjalani rawat inap di RSUP. Prof. Dr. R. D. Kandou Manado periode September-November 2016 ditemukan etiologi terbanyak yaitu penyakit jantung koroner $(73,1 \%)$, faktor pencetus terbanyak yaitu hipertensi tidak terkontrol $(41,0 \%)$.

Gambaran pasien gagal jantung akut yang menjalani rawat inap di RSUP. Prof. Dr. R.D. Kandou Manado periode September-November 2016 ditemukan fraksi ejeksi terbanyak yaitu $>50 \%$ $(41,0 \%)$.

Gambaran pasien gagal jantung akut yang menjalani rawat inap di RSUP. Prof. Dr. R. D. Kandou Manado periode September-November 2016 ditemukan obat-obatan terbanyak selama di rumah sakit yaitu pengobatan dengan penyekat EKA/ARB $(100,0 \%)$ dan obat-obatan pulang terbanyak yaitu pengobatan dengan penyekat EKA/ARB $(100,0 \%)$.

\section{DAFTAR PUSTAKA}

1. Rampengan SH. Buku Praktis Kardiologi. Jakarta;2014.

2. Masengi KGD, Ongkowijaya J, Wantania FE. Hubungan hiperurisemia dengan kardiomegali pada pasien gagal jantung kongestif. Jurnal e-Clinic (eCl);2016. 4(1).

3. Nasif M. Epidemiology. Dalam: Congestive heart failure and public health. Alahmad A;2006.:1-2.

4. Kementerian Kesehatan RI. Badan Litbangkes Kementerian Kesehatan RI dan Data Penduduk Sasaran. Data Riset Kesehatan Dasar;2013:2-4

5. Siswanto BB. Accurate diagnoses, evidence based drugs, and new devices (3 Ds) in heart failure. Med $\mathrm{j}$ indones;2012.21(1).

6. Abdul M. Analisis faktor-faktor yang berhubungan dengan rawat inap ulang pasien Gagal jantung kongestif..[tesis]. Jakarta: FKUI;2010:2-3.

7. Dickstein K, Filippatos G, McMurray JJV, Ponikowski P, Stomberg A, Atar D, et al. ESC Guidelines for the diagnosis and treatment of acute and chronic heart failure 2008. ESC;2008.10(10):933-89.

8. Harikatang AD, Rampengan SH, Jim EL. Hubungan antara jarak tempuh tes jalan 6 menit dan fraksi ejeksi pada pasien gagal jantung kronik terhadap kejadian kardiovaskular. [Skripsi]. Universitas Sam Ratulangi : Manado;2016.

9. Manurung D, Muhadi. Gagal Jantung Akut. Buku Ilmu Penyakit Dalam. Jakarta;2014: 1136-147.

10. Susan MJ, Cedars AM, et al. Acute Decompensated Heart Failure. Jurnal Texas Heart Institute;2009.36(6): 51020.

11. Stomberg A, Martensson J. Gender Differences in Patient with Heart Failure. Eur J Cardiovasc Nurs; April 2003.2: 7-18.

12. University of Maryland Medical Center. Aging changes in the heart and blood vessels. 2015. [dikutip 2016 Januari 2018] Available from : http://umm.edu/health/medical/ency/art icles/aging-changes-in-the-heart-andblood-vessels.

13. Mayo Clinic. Diseases and conditions heart failure. 2016. Available from : http://www.mayoclinic.org/diseasesconditions/heartfailure/basics/causes/con-20029801.

14. Kandou GD. Makanan etnik minahasa dan kejadian penyakit jantung koroner. Jurnal Fakultas Kesehatan Masyarakat Nasional. Agustus 2009.4:42-46.

15. University of Maryland Medical Center. Heart failure. 2012. Available from : 
http://umm.edu/health/medical/reports/ articles/heart-failure.

16. Oprail S, Calhoun DA. Managing the patient with hard to control hypertension. $\quad A m \quad$ Fam Physician; 1998.1;57(5):1007-14.

17. Waris KS, Lassus J, et al. Characteristics, outcomes, and predictors of 1-year mortality in patients hospitalized for acute heart failure. Eur Heart Jurnal;2006. 27:3011-17 .

\section{Andersson Charlotte,}

Vasan
Ramachandran S. Epidemiology of Heart Failure with Preserved Ejection Fraction. Heart Fail Clin.;2014.10(3): 377-388 .

19. National Medicines Information Centre. Chronic Heart Failure;2012. Vol. 18

20. Nieminen MS, Brutsaert D, et al. EuroHeart Failure Survey II (EHFS II): a survey on hospitalized acute heart failure patients: description of population. European Heart Journal;2006.27:2725-2736. 